\title{
GRAVE'S OPHTHALMOPATHY IN PATIENT WITH OVERT HYPOTHYROIDISM : A CASE REPORT
}

\author{
Vinayak Sawardekar1, Hitesh Mahale², Siddhesh Rane3, Swapnil Walke4, V. K. Joglekar ${ }^{5}$
}

\begin{abstract}
${ }^{1}$ Associate Professor, Department of Medicine, Grant Government Medical College and Sir JJ Group of Hospitals, Mumbai. 2Junior Resident $3^{\text {rd }}$ year, Department of Medicine, Grant Government Medical College and Sir JJ Group of Hospitals, Mumbai. 3 Junior Resident $2^{\text {nd }}$ year, Department of Medicine, Grant Government Medical College and Sir JJ Group of Hospitals, Mumbai. ${ }^{4} J u n i o r$ Resident $3^{\text {rd }}$ year, Department of Medicine, Grant Government Medical College and Sir JJ Group of Hospitals, Mumbai. 5 Professor \& HOD, Department of Medicine, Grant Government Medical College and Sir JJ Group of Hospitals, Mumbai.
\end{abstract}

ABSTRACT: Graves' ophthalmopathy in a hypothyroid patient without treatment for hyperthyroidism is called hypothyroid Graves' ophthalmopathy. We report a case of Graves' ophthalmopathy presenting with overt hypothyroidism who was not treated for hyperthyroidism previously.

KEYWORDS: Hypothyroidism, Graves Ophthalmopathy, TSH Receptor Antibody, Methylprednisolone.

HOW TO CITE THIS ARTICLE: Vinayak Sawardekar, Hitesh Mahale, Siddhesh Rane, Swapnil Walke, V. K. Joglekar. "Grave's Ophthalmopathy in Patient with overt Hypothyroidism : A Case Report". Journal of Evolution of Medical and Dental Sciences 2015; Vol. 4, Issue 91, November 12; Page: 15702-15704, DOI: 10.14260/jemds/2015/2262.

INTRODUCTION: Graves' ophthalmopathy, also known as Graves' orbitopathy or thyroid-associated ophthalmopathy, is an ophthalmic disorder with potential to cause vision loss. ${ }^{1}$ The prevalence of Graves' ophthalmopathy (GO) among Graves' disease patient's is $28 \%$, according to a study from North India. ${ }^{2}$ Though it is generally observed in patients with hyperthyroidism due to Graves' disease, it can also be seen in patients with hypothyroid patient with chronic autoimmune thyroiditis. ${ }^{3}$ Opthalmopathy is present is about quarter to half of the patients with Graves' hyperthyroidism and sometimes in patients with Hashimoto's thyroiditis. ${ }^{1}$ We report a case of Graves' ophthalmopathy with overt hypothyroidism who did not receive treatment for hyperthyroidism before.

CASE REPORT: A 30 year old male patient was admitted with chief complaints of redness and gritty sensation in both eyes since past two months. He also complained about protrusion of both eyeballs; right sided being more prominent than left eye. The protrusion present since one year progressively increased since last four months. There was no history of fever, weight loss, morning stiffness, trauma or lower back pain. Signs suggestive of hyperthyroidism were absent.

The patient was a known case of autoimmune hypothyroidism for which he was receiving 50 microgram thyroxine once daily. Personal history revealed occasional intake of alcoholic but no smoking.

PHYSICAL EXAMINATION: On examination, vital parameters (Temperature, pulse rate, respiratory rate and blood pressure) were stable. Protrusion of eyes was present visble bilaterally (Figure 1).

Financial or Other, Competing Interest: None.

Submission 26-10-2015, Peer Review 27-10-2015,

Acceptance 02-11-2015, Published 11-11-2015.

Corresponding Author:

Dr. Vinayak Sawardekar,

Associate Professor, Department of Medicine,

Grant Government Medical College \& Sir JJ Group of Hospitals,

Mumbai-400008.

E-mail: vinayaks1812@gmail.com

DOI:10.14260/jemds/2015/2262.
Opthalmological Examination:

- Vision: 6/12 on both sides

- B/l Proptosis +

- B/l congestion +

- Exophthalmometry: b/l eye $28 \mathrm{~mm}$.

- Moebius sign-present (No convergence)

There were no other eye signs. Systemic examination was normal. Investigations including ECG and chest X ray were normal. The thyroid profile (before and on admission) of the patient is shown in Table 1 .

Ultrasound of neck revealed changes suggestive of diffuse fibrosis involving both the lobes and isthmus which were possibly secondary to prior episodes of thyroiditis. Bilateral orbital ultrasound showed diffusely prominent $b / l$ retro orbital fat. Magnetic resonance imaging (MRI) of the orbit was planned but could not be performed because of the patient's non-cooperation.

The patient treated with injection methylprednisolone pulse therapy following by tapering doses of steroid. Injection methyl prednisolone was started in the dose of $500 \mathrm{mg}$ intravenously slowly over two hours once a week for six weeks followed by $250 \mathrm{mg}$ intravenously slowly over two hours once a week for next six weeks. For hypothyroidism, tablet thyroxine 75 microgram once daily was started and was advised to continue it.

Thyroid profile and opthalmological assessment was performed every six weeks. With this management, the patient improved symptomatically and clinically after six months.

DISCUSSION: Orbital fibroblasts and adipocytes cause growth of orbital content resulting in clinical manifestations. Autoreactive T lymphocytes of thyroid origin trigger the autoimmune reactions in thyroid and orbital area. ${ }^{4}$ About $10 \%$ patients with thyroid associated orbitopathy are euthyroid and hypothyroid. ${ }^{5}$

Various factors including tobacco use, elderly age group and treatment of hyperthyroidism can affect severity of ophthalmopathy in Graves' disease. ${ }^{6}$ 
Graves' ophthalmopathy has been linked to cigarette smoking.7,8 with strong evidence for a causal association between smoking and development of Grave's opthalmopathy.

Our patient was 30 years old without history of treatment for hyperthyroidism and he was not a smoker. The other possibilities for ophthalmopathy in our case could be genetics or thyroid stimulating hormone (TSH) receptor antibody levels. Elevated thyroid stimulating hormone (TSH) receptor antibody levels in this patient indicates the possibility of its etiological role in Graves' ophthalmopathy.

Expression of the TSH receptors has been found to be increased in orbital preadipocytes. ${ }^{9}$ The pathophysiology includes antibody-mediated reaction against the TSH receptor with orbital fibroblast modulation. The lymphocytic infiltration leading to inflammation and interstitial oedema of the extraocular muscles and enhanced production of glycosaminoglycans by orbital fibroblasts contributes to the pathology of the disease. ${ }^{10}$

The objective of the treatment is to achieve the euthyroid state. Along with the local supportive measures.11 the main medical treatment is glucocorticoids. ${ }^{4}$

High dose intravenous methylprednisolone pulse therapy has been shown to be effective in the management of thyroid-associated ophthalmopathy. Intravenous methylprednisolone may provide advantage over oral prednisone therapy in regards to additional therapy requirement. ${ }^{12}$ In this case we used methylprednisolone pulse therapy with good outcome.

Immunosuppressive agents have also been tried in the Graves' ophthalmopathy due to its auto-immune nature. Somatostatin analogues, antioxidants and monoclonal antibodies are the other novel treatment options for medical management. ${ }^{10}$ Orbital radiotherapy and orbital decompression may be required required in some patients. ${ }^{4}$

CONCLUSION: Graves' ophthalmopathy in a hypothyroid patient can be treated with methylprednisolone pulse therapy and thyroxin supplementation. This therapy is effective and well tolerated without any adverse events.

\section{REFERENCES:}

1. Bahn RS, Heufelder AE. Pathogenesis of Graves' ophthalmopathy. N Engl J Med. 1993;329;20:1468-75.

2. Reddy SVB, Jain A, Yadav SB, Sharma K, Bhatia E. Prevalence of Graves' ophthalmopathy in patients with Graves' disease presenting to a referral centre in north India. Indian J Med Res 2004;139: 99-104.

3. Bahn, Rebecca S."Graves' Ophthalmopathy". New England Journal of Medicine 2010; 362; 8: 726-38.

4. Bartalena L, Wiersinga WM, Pinchera A. Graves' ophthalmopathy: state of the art and perspectives. J Endocrinol Invest 2004; 27: 295-301.

5. Bartelena L, Tanda ML. Clinical practice-Grave's ophthalmopathy. N Engl J Med. 2009;360;10:994-1001.

6. Maheshwari R, Weis E. Thyroid associated orbitopathy. Indian J Opthalmol 2012;60;2:87-93.
7. Tellez M, Cooper J, Edmonds C. Graves' ophthalmopathy in relation to cigarette smoking and ethnic origin. Clin Endocrinol (Oxf) 1992;36;3:291-4.

8. Hagg E, Asplund K. Is endocrine ophthalmopathy related to smoking? Br Med J (Clin Res Ed) 1987;295;6599:634-5.

9. Valyasevi RW, Erickson DZ, Harteneck DA, Dutton CM, Heufelder AE, Jyonouchi SC, Bahn RS. Differentiation of human orbital preadipocyte fibroblasts induces expression of functional thy-rotropin receptor. J Clin Endocrinol Metab 1999; 84: 2557-62.

10. Shah Y. Thyroid Ophthalmopathy. Supplement to J Physician Assoc India.2011; 59;60-65.

11. Bahn RS. Graves' Ophthalmopathy. Engl J Med. 2010 February 25; 362;8: 726-738.

12. Kauppinen-Makelin R, Karma A, Leinonen E, Loyttyniemi E, Salonen O, Sane T, Setala K, Viikari J, Heudelder A, Valimaki M. High dose intravenous methylprednisolone pulse therapy versus oral prednisone for thyroidassociated ophthalmopathy. Acta Opthalmol Scand 2002;80;3:316-21.
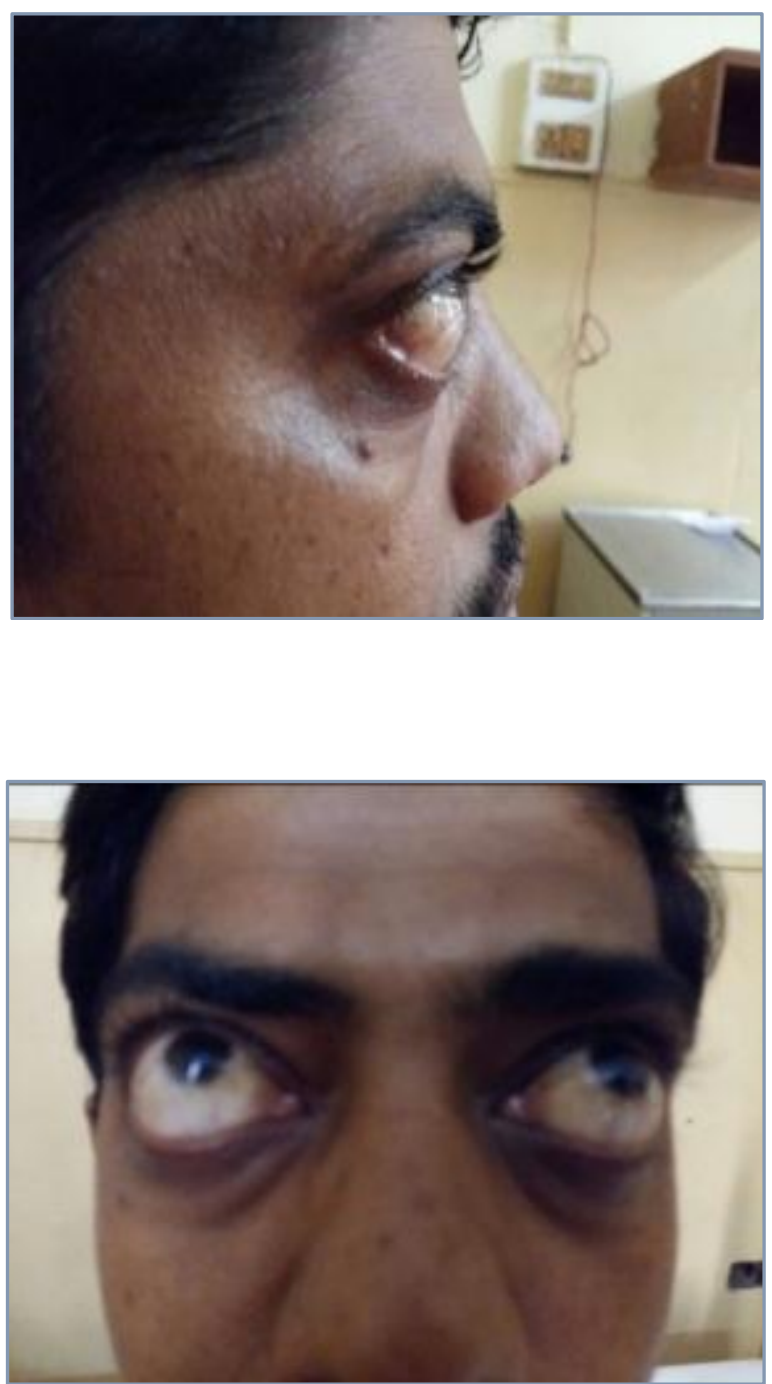

Fig.1: Protrusion of Eyes 


\begin{tabular}{|c|c|c|c|}
\hline \multicolumn{2}{|c|}{$\begin{array}{c}\text { Before Admission } \\
(13 / 08 / 2014)\end{array}$} & Parameter \\
(16/5/2015) & $\begin{array}{c}\text { Value } \\
\text { (Normal range) }\end{array}$ \\
\hline Parameter & Value (Normal Range) & TSH & $21.9 \mathrm{uIU} / \mathrm{ml}(0-8-2)$ \\
\hline $\mathrm{TSH}$ & $>150 \mathrm{uIU} / \mathrm{ml}(0.3-5.5)$ & TSH-FT3 & $2.98 \mathrm{pg} / \mathrm{ml}(1.8-4.2)$ \\
\hline $\mathrm{T} 3$ & $61 \mathrm{pg} / \mathrm{ml}(60-200)$ & $\mathrm{FT} 4$ & $1.07 \mathrm{ng} / \mathrm{ml}(0-8-2)$ \\
\hline $\mathrm{T} 4$ & $3.4 \mathrm{ng} / \mathrm{ml}(4.5-12)$ & Antimicrosomal antibodies $(\mathrm{AMA} / \mathrm{anti} \mathrm{TPO})$ & $>600 \mathrm{IU} / \mathrm{ml}(<34)$ \\
\hline & & Antithyroglobulin antibodies $(\mathrm{ATG})$ & $383.1 \mathrm{IU} / \mathrm{ml}(<115)$ \\
\hline & & TSH Receptor antibody Ig & $24.97 \mathrm{IU} / \mathrm{L}(\mathrm{n}<1.75)$ \\
\hline & & Table 1: Thyroid profile \\
\hline
\end{tabular}

